\title{
Hybrid Multiattribute Decision Method for Material Selection
}

\author{
Mehmet Şahin \\ Iskenderun Technical University, Department of Industrial Engineering, 31200 Iskenderun, Turkey \\ mehmet.sahin@simon.rochester.edu $\mathrm{DD}$ \\ Received date: 16.10.2020, Accepted date: 26.12.2020
}

\begin{abstract}
Material selection is crucial in product design. The appropriate material selection for a specific product is an essential task for engineers. The triggering reasons for the appropriate material selection are often to minimize cost and improve performance. However, depending on the area where the material is used, the scope and importance of the attributes vary. The availability of numerous materials with various features complicate the material selection process. In this regard, to choose the best alternative material for a particular application, an efficient, systematic approach to material selection is required. In this study, a hybrid multicriteria decision approach is proposed for material selection. The importance of attributes (weight) is determined through the standard deviation and criteria importance through intercriteria correlation methods. Considering the fact that the outcome of multiple attribute decision-making (MADM) methods is dependent on the weights of the criteria, the objective weighting methods are preferred to avoid subjective assessments. The ranking of alternative materials is achieved through grey relational analysis, technique for order performance by similarity to ideal solution, and organization rangement et synthese de donnes relationnelles (ORESTE). The main reason for utilizing several MADM methods is the fact that any of them does not guarantee the right choice. Therefore, the ranks provided six models are integrated via the Copeland method to reveal a final consensus ranking. The weighting methods' results indicate that the weight of an attribute can be the highest and lowest depending on what weighting method is preferred. The result of the Copeland method reveals that the final consensus rank of materials can be different from the rank of the models. Thus, considering and integrating of multiple models is essential.
\end{abstract}

Keywords: Copeland, grey relational analysis, material selection, multiple attribute decision making

\section{Malzeme Seçimi için Hibrit Çok Kriterli Karar Yöntemi}

\section{Öz}

Ürün tasarımında malzeme seçimi oldukça önemlidir. Belirli bir ürün için uygun malzeme seçimi, mühendisler için temel bir görevdir. Uygun malzeme seçimi için temel hedefler genellikle maliyeti en aza indirmek ve performansı iyileştirmektir. Bununla birlikte, malzemenin kullanıldığı alana bağlı olarak, özelliklerin kapsamı ve önemi değişisir. Çeşitli özelliklere sahip çok sayıda malzemenin mevcudiyeti, malzeme seçim sürecini zorlaştırmaktadır. Bu bağlamda, belirli bir uygulamaya yönelik en iyi alternatif malzemeyi seçmek için verimli ve sistematik bir yaklaşım gerekmektedir. Bu çalışmada, malzeme seçimi için hibrit çok kriterli bir karar yaklaşımı önerilmiştir. Niteliklerin önemi (ağırlıkları), standart sapma ve kriterler arası korelasyon yöntemleri ile kriter önemi ile belirlenir. Çok kriterli karar verme yöntemlerinin sonucunun kriterlerin ağırlıklarına bağlı olduğu gerçeği dikkate alındığında, öznel değerlendirmelerden kaçınmak için nesnel ağırlıklandırma yöntemleri tercih edilmiştir. Alternatif malzemelerin sıralaması, gri ilişkisel analiz, ideal çözüme benzerlik yoluyla sipariş performansı için teknik ve organization rangement et synthese de donnes relationnelles (ORESTE) yoluyla elde edilir. Birkaç çok kriterli karar verme yönteminin kullanılmasının ana nedeni, bunlardan herhangi birinin doğru seçimi garanti etmemesidir. Bu nedenle, nihai bir fikir birliği sıralamasını ortaya çıkarmak için altı modelin Copeland yöntemiyle entegre edildiği sıralamalar elde edilmektedir. Ağırlıklandırma yöntemlerinin sonuçları, bir kriterin ağırlığının, hangi ağırlıklandırma yönteminin tercih edildiğine bağlı olarak en yüksek ve en düşük olabileceğini göstermektedir. Copeland yönteminin sonucu, malzemelerin nihai konsensüs sıralamasının modellerin sıralamasından farklı olabileceğini ortaya koymaktadır. Bu nedenle, birden fazla modelin dikkate alınması ve entegre edilmesi oldukça önemlidir.

Anahtar Kelimeler: Copeland, gri ilişkisel analiz, malzeme seçimi, çok kriterli karar verme 


\section{INTRODUCTION}

The availability of a wide variety of materials and their critical role in designing, manufacturing, and marketing a product make the material selection decision vital (Chatterjee et al., 2011). This selection decision involves numerous conflicting attributes (Emovon et al., 2020). Depending on the application area's priorities and requirements, the scope and significance level of attributes may vary. Although cost is generally one of the essential criteria (attributes) in material selection, compulsory tradeoffs such as quality being more critical than cost may cause differences in the criteria' importance level.

The possible consequences of choosing inappropriate material can have devastating effects (Kumar et al., 2014). For example, short- and longterm impacts of customers whose expectations are not met, high cost, low productivity, damage or failure of an assembly, and poor performance can be a short and clear explanation of some possible results. Since these concepts directly affect businesses' continuity, there is no need to specify these concepts' importance. Therefore, material selection and determining a practical solution approach for this problem are among the essential topics in the literature.

Multiple attribute decision making (MADM) methods have been frequently applied for such problems. Jahan et al. (2011) used vise kriterijumska optimizacija ikompromisno resenje (VIKOR) to rank and chose the best material. Jeya Girubha et al. (2012) implemented fuzzy VIKOR to the material selection of an automotive component and found that Polypropylene could be an alternative material for the instrument panel. Dev et al. (2020) adopted the entropy method to determine attribute weights and the VIKOR method to select optimal material for the automotive piston component. Shanian et al. (2006) used elimination and choice expressing the reality (ELECTRE) to determine the ranking of materials for a loaded thermal conductor's specific application. Maity et al. (2015) proposed an approach based on the preference ranking organization method for enrichment evaluation (PROMETHEE II) to determine the best and worst material alternatives for the tool material selection problem. Maity et al. (2013) implemented a fuzzy technique for order performance by similarity to ideal solution (TOPSIS) to solve the grinding wheel abrasive material selection problem. Chan et al. (2007) used grey relational analysis (GRA) to rank the materials.
In addition, more than one MADM method was used in some studies. Yazdani et al. (2016) used stepwise weight assessment ratio analysis (SWARA), multi-objective optimization on the basis of ratio analysis (MOORA), and weighted aggregated sum product assessment (WASPAS) methods and examined their ranking results. Madhu et al. (2020) used fuzzy AHP, TOPSIS, VIKOR, evaluation based on distance from average solution (EDAS), and PROMETHEE II to determine optimal biomass material. Dhanalakshmi et al. (2020) implemented fuzzy AHP, TOPSIS, and EDAS methods for pyrolysis material selection. Niu et al. (2020) adopted AHP, entropy, and complex proportional assessment (COPRAS) to select cutting tool material.

The literature review reveals that the MADM methods have been successfully implemented for solving material selection problems in different application areas. The majority of the studies included one MADM method. However, the number of hybrid approaches has been increasing recently. Depending on the result of one MADM method can be misleading as the MADM method's rank is sensitive to the attribute weights. Therefore, adopting multiple MADM methods improves the exactness of the ranking result (Şahin, 2020b). Also, entropy is preferred mostly as the weighting method for material selection problems. Unlike other studies, this study proposes a hybrid MADM approach based on criteria importance through intercriteria correlation (CRITIC), standard deviation (SD), GRA, TOPSIS, organization rangement et synthese de donnes relationnelles (ORESTE), Kendall's correlation coefficient, and the Copeland method.

In the proposed integrated approach, SD and CRITIC methods provide the attribute weight sets. The importance of each attribute is determined based on the SD and CRITIC algorithms. Thus, the impact of attribute weights on the ranking of alternatives can be detected. Also, three different MADM - GRA, ORESTE, and TOPSIS methods from different MADM categories are implemented to rank alternative materials. Thus, the differences between ranks provided by each method are revealed to allow comparisons and provide ranks through different models. Then, correlations between each model are examined. Finally, six models' rankings are integrated using the Copeland method to suggest a final consensus ranking considered to be more precise than a model. 
The contributions of the present study can be summarized as follows. It is not to mention again that this study presents a unique hybrid approach involving various methods for solving material selection problems. The outcomes of different method pairs (models) are examined to reveal the correlations between models. Last, the final consensus ranking is achieved based on integrating several methods through the Copeland method, meaning that the rank's accuracy is higher than one method implemented in most other related studies.

The remainder of the study is organized as follows: The following section presents the methods used, proposed methodology, and details of the problem. Section 3 then provides the results and related discussions. Finally, Section 4 concludes the study, along with the study's limitations and recommendations for future studies.

\section{MATERIAL AND METHODS}

This section describes the weighting and MADM methods used in the present study initially. As explained earlier, CRITIC and SD are implemented to obtain the attribute weights. The reasons for choosing these weighting methods are to reveal the impact of attribute weights on ranking results, and unlike other studies using the entropy method, to utilize the CRITIC and SD methods to allow comparisons. Besides, GRA, ORESTE, and TOPSIS are implemented to rank alternative materials. The reasons for choosing these methods are to use methods from different categories, utilize methods proven successful in solving problems in various fields and reveal potential ranking differences. The reasons for choosing multiple weighting and MADM methods are to allow comparisons, obtain rankings from different models, and integrate them to determine the final ranking based on a final consensus. In this regard, the Copeland method is implemented. Subsequently, the details of the proposed approach and the implementation of the approach to the material selection problem is explained.

\section{CRITIC}

The weights are calculated through the contrast intensity and conflict assessment. This method assigns high importance to the responses with high standard deviation and low correlation with other responses. The procedure of the method can be described, as follows (Diakoulaki et al., 1995):

i. The normalization of the decision matrix is performed through Equation 1.

$$
a_{i j}^{+}=\frac{a_{i j}-a_{j}{ }^{\text {worst }}}{a_{j}{ }^{\text {best }}-a_{j}^{\text {worst }}}
$$

where $a_{i j}^{+}$represents the normalized value of the $i$ th design on the $j$ th response.

ii. The information amount contained in the $j$ th response is calculated through the following multiplicative aggregation equation.

$$
C_{j}=\sigma_{j} \sum_{k=1}^{n}\left(1-r_{j k}\right)
$$

where $\sigma_{j}$ represents the standard deviation of the $j$ th response and $r_{j k}$ denotes the correlation coefficient between two different responses.

iii. Attribute weights $\left(w_{\mathrm{j}}\right)$ are calculated through Equation 3.

$$
w_{j}=\frac{C_{j}}{\sum_{k=1}^{m} C_{k}}
$$

SD

SD assigns the weights of criteria according to their standard deviations via Equation 4 (H. Deng et al., 2000).

$$
w_{j}=\frac{\sigma_{j}}{\sum_{k=1}^{m} \sigma_{k}}, \quad j=1,2, \ldots, m
$$

\section{GRA}

J.-L. Deng (1982) introduced the GRA. The GRA examines the uncertain relationships between a major factor and all other factors in a system (Liang, 1999). GRA's main advantages include its robustness, practicality, objectivity, computational efficiency, and simplicity (Wei, 2011; Wu, 2002). Assuming that there are $m$ alternatives and $n$ attributes and the vector of the reference sequence and comparability sequences are denoted by $X_{0}=\left(x_{01}, x_{02}, \ldots, x_{0 n}\right)$ and $X_{i}=\left(x_{i 1}, x_{i 2}, \ldots, x_{i n}\right)$, respectively. $Y_{\mathrm{i}}$ represents the original vector for the value of attributes of each alternative and converted to the comparability sequence after the normalization process. The steps for grey relational analysis are as follows: 
Step 1. The data is normalized in the context of data preprocessing to eliminate different intervals and units in the dataset. The normalization of the data for beneficial and nonbeneficial attributes is conducted based on the following equations:

$$
\begin{array}{r}
x_{i j}=\frac{y_{i j}-\min \left(y_{i j}\right)}{\max \left(y_{i j}\right)-\min \left(y_{i j}\right)}, \text { for } i= \\
1,2, \ldots, m ; j=1,2, \ldots, n \\
x_{i j}=\frac{\max \left(y_{i j}\right)-y_{i j}}{\max \left(y_{i j}\right)-\min \left(y_{i j}\right)}, \text { for } i= \\
1,2, \ldots, m ; j=1,2, \ldots, n
\end{array}
$$

$y_{\mathrm{ij}}$ represents the jth attribute's numerical value for the $i$ th alternative, and $x_{\mathrm{ij}}$ is the normalized value.

Step 2. The grey relational coefficient calculation, which indicates the relationship between the reference sequence and comparability sequence, is performed using the following equation.

$$
\gamma\left(x_{0 j}, x_{i j}\right)=\frac{\Delta_{\min }+\xi \Delta_{\max }}{\Delta_{i j}+\xi \Delta_{\max }}
$$

where $x_{0 j}$ represents the reference sequence and $x_{i j}$ is the comparative sequence,

$$
\begin{gathered}
\Delta_{i j}=\left|x_{0 j}-x_{i j}\right| \\
\Delta_{\min }=\operatorname{Min}\left\{\Delta_{i j}, i=1,2, \ldots, m ; j\right. \\
=1,2, \ldots, n\} \\
\Delta_{\max }=\operatorname{Max}\left\{\Delta_{i j}, i=1,2, \ldots, m ; j\right. \\
=1,2, \ldots, n\}
\end{gathered}
$$

$\xi$ denotes the distinguishing coefficient and $\xi \in$ $(0,1)$. In this study, it is taken as 0.5 as commonly used in the literature.

Step 3. The calculation of grey rational grade is performed through the following equation. Here, $\Gamma\left(X_{0}, X_{i}\right)$ denotes the correlation level between the reference sequence and comparability sequence. The higher value of the gray rational grade indicates the optimum alternative.

$$
\begin{gathered}
\Gamma\left(X_{0}, X_{i}\right)=\sum_{j=1}^{n} w_{j} \gamma\left(x_{0 j}, x_{i j}\right) \text { for } i \\
=1,2, \ldots, m
\end{gathered}
$$

where $w_{\mathrm{j}}$ represents the weighting coefficient of factors and $\sum_{j=1}^{n} w_{j}=1$.

\section{ORESTE}

The algorithm of ORESTE is described in the following steps (Roubens, 1982).

1. The global preference score $\widetilde{D}\left(a_{i j}\right)$ is determined based on the following equation.

$$
\begin{aligned}
& \widetilde{D}\left(a_{i j}\right) \\
& =\sqrt{\varsigma\left(r_{j}\right)^{2}+(1-\varsigma)\left(r_{j}\left(A_{i}\right)\right)^{2}}
\end{aligned}
$$

where $\boldsymbol{s}$ is a coefficient reflecting the ranking importance of attribute and alternative, and it is assigned by the decision-maker.

2. The global weak ranking $r\left(a_{i j}\right)$ is determined. The Besson's rank $r\left(a_{i j}\right)$ is obtained through the values of $\widetilde{D}\left(a_{i j}\right)(i=1,2, \ldots, m ; j=1,2, \ldots, n)$ in descending order.

3. The weak rank $R\left(A_{i}\right)$ is determined based on the following equation.

$$
R\left(A_{i}\right)=\sum_{j=1}^{n} r\left(a_{i j}\right)
$$

4. The preference intensities are obtained. The mean preference intensity between $A_{i}$ and $A_{k}$ is calculated based on the following equation.

$$
\begin{aligned}
& \tilde{T}\left(A_{i}, A_{k}\right) \\
& =\frac{\sum_{j=1}^{n} \max \left[\left(r\left(a_{k j}\right)-r\left(a_{i j}\right)\right), 0\right]}{(m-1) n^{2}}
\end{aligned}
$$

The net preference intensity between $A_{i}$ and $A_{k}$ is expressed as:

$$
\begin{aligned}
\Delta \tilde{T}\left(A_{i}, A_{k}\right)= & \tilde{T}\left(A_{i}, A_{k}\right) \\
& -\tilde{T}\left(A_{k}, A_{i}\right)
\end{aligned}
$$

5. PIR structure (preference $(\mathrm{P})$, indifference (I), and incomparability $(\mathrm{R}))$ is designed. The concept of the indifference and incomparability test (conflict analysis) is:

$$
\text { a) If }\left|\Delta \tilde{T}\left(A_{i}, A_{k}\right)\right| \leq \tilde{\mu} \text { then }
$$


$\left\{\begin{array}{l}A_{i} I A_{k}, \text { if }\left|\tilde{T}\left(A_{i}, A_{k}\right)\right| \leq \tilde{\xi} \text { and }\left|\tilde{T}\left(A_{k}, A_{i}\right)\right| \leq \tilde{\xi} \\ A_{i} R A_{k}, \text { if }\left|\tilde{T}\left(A_{i}, A_{k}\right)\right|>\tilde{\xi} \text { or }\left|\tilde{T}\left(A_{k}, A_{i}\right)\right|>\tilde{\xi}\end{array}\right.$

b) If $\left|\Delta \tilde{T}\left(A_{i}, A_{k}\right)\right|>\tilde{\mu}$ then

$$
\left\{\begin{aligned}
& A_{i} R A_{k}, \quad \text { if } \min \frac{\tilde{T}\left(A_{i}, A_{k}\right), \tilde{T}\left(A_{k}, A_{i}\right)}{\left|\Delta \tilde{T}\left(A_{i}, A_{k}\right)\right|} \geq \tilde{\lambda} \\
& A_{i} P A_{k}, \quad \text { if } \min \frac{\tilde{T}\left(A_{i}, A_{k}\right), \tilde{T}\left(A_{k}, A_{i}\right)}{\left|\Delta \tilde{T}\left(A_{i}, A_{k}\right)\right|}<\tilde{\lambda} \\
& \text { and } \tilde{T}\left(A_{i}, A_{k}\right)>\tilde{T}\left(A_{k}, A_{i}\right) \\
& A_{k} P A_{i}, \quad \text { if } \min \frac{\tilde{T}\left(A_{i}, A_{k}\right), \tilde{T}\left(A_{k}, A_{i}\right)}{\left|\Delta \tilde{T}\left(A_{i}, A_{k}\right)\right|}<\tilde{\lambda} \\
& \text { and } \tilde{T}\left(A_{i}, A_{k}\right)<\tilde{T}\left(A_{k}, A_{i}\right)
\end{aligned}\right.
$$

where $\tilde{\mu}, \tilde{\xi}$, and $\tilde{\lambda}$ denote thresholds.

6. A strong ranking is obtained. The outcome is the combination of the weak ranking and the PIR structure.

\section{TOPSIS}

TOPSIS was presented by Hwang et al. (1981). The algorithm of TOPSIS is described in the following steps:

Step 1. The decision matrix is constructed as represented as follows:

$$
\left[\begin{array}{ccc}
a_{11} & \cdots & a_{1 n} \\
\vdots & \ddots & \vdots \\
a_{m 1} & \cdots & a_{m n}
\end{array}\right]
$$

where $a_{i j}$ represents the numerical value of the $j$ th attribute for $i$ th alternative.

Step 2. The decision matrix is normalized through the following equation.

$$
\begin{array}{rl}
r_{i j}=\frac{a_{i j}}{\sqrt{\sum_{i=1}^{m} a_{i j}^{2}}} & \quad \text { for } i \\
=1,2, \ldots, m ; j & j \\
=1,2, \ldots, n
\end{array}
$$

Step 3. The weighted normalized decision matrix is obtained via the following equation.

$$
\begin{aligned}
v_{i j}=w_{j} * r_{i j} & \text { for } i \\
& =1,2, \ldots, m ; j \\
& =1,2, \ldots, n
\end{aligned}
$$

Step 4. The positive ideal solution (PIS) and negative ideal solution (NIS) for each criterion are determined via the following equations.

$$
\begin{aligned}
& P I S \\
& =\left\{\left(\max _{i} v_{i j} \mid j \in J_{1}\right),\left(\min _{i} v_{i j} \mid j \in J_{2}\right) \mid i\right. \\
& =1,2, \ldots, m\}=\left\{v_{1}^{+}, v_{2}^{+}, \ldots, v_{j}^{+}, \ldots, v_{n}^{+}\right\} \\
& \text {NIS } \\
& =\left\{\left(\min _{i} v_{i j} \mid j \in J_{1}\right),\left(\max _{i} v_{i j} \mid j \in J_{2}\right) \mid i\right. \\
& =1,2, \ldots, m\}=\left\{v_{1}^{-}, v_{2}^{-}, \ldots, v_{j}^{-}, \ldots, v_{n}^{-}\right\}
\end{aligned}
$$

in which $J_{1}$ and $J_{2}$ are the benefit and cost indicators, respectively.

Step 5. Each alternative's geometric distance from the positive and negative ideal solution is calculated through the following equations, respectively.

$$
\begin{gathered}
S_{i}^{+}=\sqrt{\sum_{j=1}^{n}\left(v_{i j}-v_{j}^{+}\right)^{2}} \text { for } i \\
=1,2, \ldots, m \\
S_{i}^{-}=\sqrt{\sum_{j=1}^{n}\left(v_{i j}-v_{j}^{-}\right)^{2}} \text { for } i \\
=1,2, \ldots, m
\end{gathered}
$$

Step 6. The relative closeness to the ideal solution is obtained via the following equation.

$$
\begin{aligned}
C_{i}=\frac{S_{i}^{-}}{S_{i}^{-}+S_{i}^{+}} & \text {for } i \\
& =1,2, \ldots, m ; 0 \\
& <C_{i}<1
\end{aligned}
$$

The rank of alternatives is determined by comparing $C_{\mathrm{i}}$ values. The alternative having the highest relative closeness is chosen as the best. 


\section{Implementation of the Proposed Approach to the Selection of Material}

The application of the proposed approach is summarized in Figure 1.

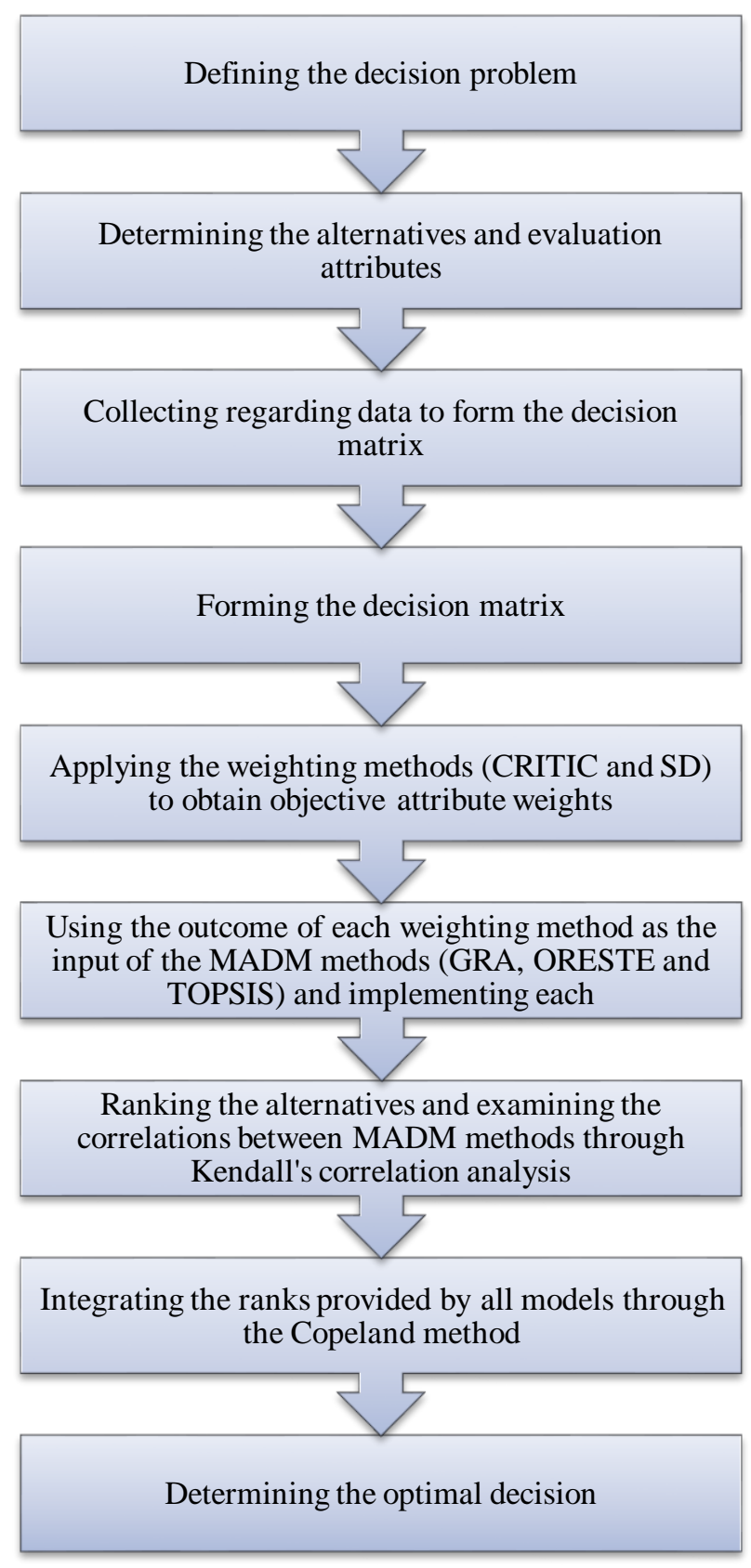

Figure 1. The steps of the proposed approach
First, the decision problem is defined. In this context, material selection for a flywheel is considered in the present study. A flywheel is a material to store kinetic energy in vehicles, including subway trains, cars, mass transit buses, and windpower generators (Jee et al., 2000). Then, ten alternative materials and four evaluation attributes are determined, as presented in Table 1 . Here, $\sigma_{\text {limit }}$ represents the fatigue limit, $\rho$ denotes the density, and $K_{\text {IC }}$ represents the fracture toughness of the material. To form the decision matrix (Table 1), regarding data is collected. In this context, the raw data is obtained from Jee et al. (2000) to evaluate the proposed model against the obtained results.

Next, the weighting methods - CRITIC and SD are implemented. While applying the weighting methods, the data needs to be normalized. The normalized data for the CRITIC method are presented as an example in Table 2. Once the attribute weight sets are obtained, they are used as input for each MADM method, namely GRA, ORESTE, and TOPSIS. After obtaining the materials' ranking from each model, the correlation between models is examined based on Kendall's correlation coefficients. Finally, all models' rank is integrated through the Copeland method to reach a final consensus ranking. Thus, the final ranking of alternatives reflects the results of six models believed to be more reliable than many other related studies that rely on a single model.

\section{RESULTS AND DISCUSSION}

The attribute weights provided by SD and CRITIC are presented in Table 3. Based on the SD method, the most critical attribute is fragmentability, followed by $\sigma_{\text {limit }} / \rho, K_{\mathrm{IC}} \rho$, and price/mass. However, according to the CRITIC method, price/mass is the most crucial attribute, followed by fragmentability, $\sigma_{\text {limit }} / \rho$, and $K_{\mathrm{IC}} \rho \rho$. It can be seen that price/mass is the most essential, and fracture toughness $\left(\mathrm{K}_{\mathrm{IC}}\right) /$ density is the least essential attribute, according to the CRITIC method. However, the most critical criterion is fragmentability and the least essential is price/mass, according to the SD method. This outcome reveals that an attribute can be the most and least essential, depending on a weighting method. Therefore, utilizing more than one weighting method can be crucial. Otherwise, being dependent on a weighting method can be misleading. 
Table 1. The decision matrix for the material selection problem (Jee et al., 2000)

\begin{tabular}{lcccc}
\hline \multicolumn{1}{c}{ Materials } & $\boldsymbol{\sigma}_{\text {limit }} / \boldsymbol{\rho}$ & $\mathbf{K}_{\mathbf{I C}} / \boldsymbol{\rho}$ & Price/mass $(\mathbf{U S} \mathbf{\text { tton} )}$ & Fragmentability \\
\hline 300M (M1) & 100.000 & 8.613 & 4200 & 3 \\
\hline 2024-T3 (M2) & 49.645 & 13.475 & 2100 & 3 \\
\hline 7050-T73651 (M3) & 78.014 & 12.553 & 2100 & 3 \\
\hline Ti-6Al-4V (M4) & 108.879 & 26.004 & 10500 & 3 \\
\hline E glass-epoxy FRP (M5) & 70.000 & 10.000 & 2735 & 9 \\
\hline S glass-epoxy FRP (M6) & 165.000 & 25.000 & 4095 & 9 \\
\hline Carbon-epoxy FRP (M7) & 440.252 & 22.013 & 35470 & 7 \\
\hline Kevlar 29-epoxy FRP (M8) & 242.857 & 28.571 & 11000 & 7 \\
\hline Kevlar 49-epoxy FRP (M9) & 616.438 & 34.247 & 25000 & 7 \\
\hline Boron-epoxy FRP (M10) & 500.000 & 23.000 & 315000 & 5
\end{tabular}

Table 2. The normalized data for the CRITIC method

\begin{tabular}{ccccc}
\hline Materials & $\boldsymbol{\sigma}$ limit $/ \boldsymbol{\rho}$ & $\mathbf{K}_{\mathbf{I C}} / \boldsymbol{\rho}$ & Price/mass (US\$/ton) & Fragmentability \\
\hline M1 & 0.089 & 0.000 & 0.993 & 0.000 \\
\hline M2 & 0.000 & 0.190 & 1.000 & 0.000 \\
\hline M3 & 0.050 & 0.154 & 1.000 & 0.000 \\
\hline M4 & 0.105 & 0.678 & 0.973 & 0.000 \\
\hline M5 & 0.036 & 0.054 & 0.998 & 1.000 \\
\hline M6 & 0.204 & 0.639 & 0.994 & 1.000 \\
\hline M7 & 0.689 & 0.523 & 0.893 & 0.667 \\
\hline M8 & 0.341 & 0.779 & 0.972 & 0.667 \\
\hline M9 & 1.000 & 1.000 & 0.927 & 0.667 \\
\hline M10 & 0.795 & 0.561 & 0.000 & 0.333 \\
\hline
\end{tabular}

Table 3. The attribute weights provided by SD and CRITIC

\begin{tabular}{lcccc}
\hline Method & $\boldsymbol{\sigma}_{\text {limit }} / \boldsymbol{\rho}$ & $\mathbf{K}_{\text {IC }} / \boldsymbol{\rho}$ & Price/mass & Fragmentability \\
\hline SD & 0.255 & 0.237 & 0.217 & 0.292 \\
\hline CRITIC & 0.247 & 0.194 & 0.303 & 0.257
\end{tabular}

Utilizing the weighting set of each weighting method as input, the MADM methods (GRA, ORESTE, and TOPSIS) are implemented. The utility values and rank obtained from each are presented in Table 4.

The results in Table 4 indicate that M9 is the best material based on CRITIC-GRA, SD-GRA, SDORESTE, CRITIC-TOPSIS, and SD-TOPSIS models. However, M6 is an optimal material according to the CRITIC-ORESTE model. Besides, the worst choice is M10 based on the CRITIC-GRA, CRITIC-TOPSIS, and SD-TOPSIS models. $\mathrm{M} 1$ is the least preferable, according to the SD-GRA, CRITIC-ORESTE, and SDORESTE models. In addition, the results reveal that the ranks provided by each model indicate that the ranking of materials varies depending on the weighting and MADM method adopted in general. However, the rankings provided by CRITIC-TOPSIS and SD-TOPSIS models are the same. This may be an indication that TOPSIS is less susceptible to attribute weights and more robust compared to GRA and ORESTE for the problem considered. In this regard, to examine the correlation between models, Kendall's correlation coefficients are obtained, as presented in Table 5. Kendall's correlation 
coefficients (Kendall, 1948) are to analyze the correlations between the models. The degree of similarity between two rank sets for the same set of alternatives is evaluated. The results indicate that the correlations between CRITIC-GRA and SD-GRA, CRITIC-GRA and CRITIC-ORESTE, CRITIC-GRA and SD-ORESTE, CRITIC-GRA and CRITICTOPSIS, CRITIC-GRA and SD-TOPSIS, SD-GRA and CRITIC-ORESTE, SD-GRA and SD-ORESTE, CRITIC-ORESTE and SD-ORESTE are significant. Also, there is a perfect correlation between CRITICTOPSIS and SD-TOPSIS. In other words, the strong correlation indicates that the ranks provided by models are similar to some extent.

To reach a final consensus on the ranking of alternative materials, the Copeland method is implemented. In the Copeland method, it is considered how many times an alternative is dominant over others in the ranking of alternatives. In this context, pairwise comparison matrices are constructed for each model. To obtain the score of the alternatives in the matrices, a value of one is given for all other alternatives that rank below the selected alternative; otherwise, a zero value is given to the corresponding matrix value. After obtaining all values for matrices, the column sum and row sum for each alternative are computed. The Copeland value of an alternative is determined by taking the difference between the row and column sums (Dortaj et al., 2020; Sahin, 2020a). Hence, the rankings provided by six models are integrated.

Table 4. Utility and ranking values provided by models

\begin{tabular}{|c|c|c|c|c|c|c|c|c|c|c|c|c|}
\hline \multirow[t]{3}{*}{ Alternatives } & \multicolumn{12}{|c|}{ Models } \\
\hline & \multicolumn{2}{|c|}{ CRITIC-GRA } & \multicolumn{2}{|c|}{ SD-GRA } & \multicolumn{2}{|c|}{ CRITIC-ORESTE } & \multicolumn{2}{|c|}{ SD-ORESTE } & \multicolumn{2}{|c|}{ CRITIC-TOPSIS } & \multicolumn{2}{|c|}{ SD-TOPSIS } \\
\hline & Utility & Rank & Utility & Rank & Utility & Rank & Utility & Rank & Utility & Rank & Utility & Rank \\
\hline M1 & 0.134 & 9 & 0.120 & 10 & 115.5 & 10 & 116.5 & 10 & 0.636 & 8 & 0.534 & 8 \\
\hline M2 & 0.136 & 8 & 0.122 & 9 & 100 & 9 & 109 & 9 & 0.631 & 9 & 0.532 & 9 \\
\hline M3 & 0.136 & 7 & 0.122 & 8 & 93 & 8 & 102 & 8 & 0.637 & 7 & 0.538 & 7 \\
\hline M4 & 0.145 & 6 & 0.135 & 6 & 92 & 7 & 86.5 & 6 & 0.657 & 6 & 0.569 & 6 \\
\hline M5 & 0.177 & 3 & 0.169 & 3 & 82 & 5 & 88 & 7 & 0.666 & 5 & 0.583 & 5 \\
\hline M6 & 0.191 & 2 & 0.185 & 2 & 50 & 1 & 52 & 2 & 0.726 & 4 & 0.661 & 4 \\
\hline M7 & 0.164 & 5 & 0.158 & 5 & 79.5 & 4 & 76.5 & 4 & 0.806 & 2 & 0.759 & 2 \\
\hline M8 & 0.170 & 4 & 0.164 & 4 & 65.5 & 3 & 57.5 & 3 & 0.752 & 3 & 0.689 & 3 \\
\hline M9 & 0.215 & 1 & 0.214 & 1 & 55.5 & 2 & 48 & 1 & 0.904 & 1 & 0.887 & 1 \\
\hline M10 & 0.122 & 10 & 0.126 & 7 & 87 & 6 & 84 & 5 & 0.289 & 10 & 0.367 & 10 \\
\hline
\end{tabular}

Table 5. Kendall's correlation coefficients of models

\begin{tabular}{lllllll}
\hline Models & $\begin{array}{l}\text { CRITIC- } \\
\text { GRA }\end{array}$ & $\begin{array}{l}\text { SD- } \\
\text { GRA }\end{array}$ & $\begin{array}{l}\text { CRITIC- } \\
\text { ORESTE }\end{array}$ & $\begin{array}{l}\text { SD- } \\
\text { ORESTE }\end{array}$ & $\begin{array}{l}\text { CRITIC- } \\
\text { TOPSIS }\end{array}$ & $\begin{array}{l}\text { SD- } \\
\text { TOPSIS }\end{array}$ \\
\hline CRITIC-GRA & 1.000 & $0.867^{* *}$ & $0.689^{* *}$ & $0.644^{* *}$ & $0.733^{* *}$ & $0.733^{* *}$ \\
\hline SD-GRA & & 1.000 & $0.822^{* *}$ & $0.778^{* *}$ & $0.600^{*}$ & $0.600^{*}$ \\
\hline CRITIC-ORESTE & & & 1.000 & $0.867^{* *}$ & $0.600^{*}$ & $0.600^{*}$ \\
\hline SD-ORESTE & & & 1.000 & $0.556^{*}$ & $0.556^{*}$ \\
\hline CRITIC-TOPSIS & & & & & 1.000 & $1.000^{* *}$ \\
\hline SD-TOPSIS & & & & & & 1.000
\end{tabular}

**. Correlation is significant at the 0.01 level (2-tailed).

*. Correlation is significant at the 0.05 level (2-tailed). 
Table 6. Calculations for the Copeland method

\begin{tabular}{lcccccccccccc}
\hline & M1 & M2 & M3 & M4 & M5 & M6 & M7 & M8 & M9 & M10 & Row Sum & Difference \\
\hline M1 & 0 & 0 & 0 & 0 & 0 & 0 & 0 & 0 & 0 & 0 & 0 & -9 \\
\hline M2 & 1 & 0 & 0 & 0 & 0 & 0 & 0 & 0 & 0 & 0 & 1 & -7 \\
\hline M3 & 1 & 1 & 0 & 0 & 0 & 0 & 0 & 0 & 0 & 0 & 2 & -5 \\
\hline M4 & 1 & 1 & 1 & 0 & 0 & 0 & 0 & 0 & 0 & 1 & 4 & -1 \\
\hline M5 & 1 & 1 & 1 & 1 & 0 & 0 & 0 & 0 & 0 & 1 & 5 & 1 \\
\hline M7 & 1 & 1 & 1 & 1 & 1 & 0 & 1 & 1 & 0 & 1 & 8 & 7 \\
\hline M8 & 1 & 1 & 1 & 1 & 1 & 0 & 0 & 0 & 0 & 1 & 6 & 3 \\
\hline M10 & 1 & 1 & 1 & 1 & 1 & 0 & 1 & 0 & 0 & 1 & 7 & 5 \\
\hline Column Sum & 1 & 1 & 1 & 1 & 1 & 1 & 1 & 1 & 0 & 1 & 9 & 9 \\
\hline
\end{tabular}

The final calculations for the Copeland method are given in Table 6. Here, the row sum of the alternatives was determined based on six pairwise comparison matrices. For instance, the row sum of M9 equals 9, meaning that M9 dominated all other alternatives in most models. The column sum of M9 is equal to 0 , which means other alternatives in most models could not subordinate M9. As stated earlier, the difference values corresponding to the alternative are the difference between the row sum and column sum values of each alternative.

Based on the difference values in Table 6, the final consensus ranking of the materials is obtained, as presented in Table 7 .

Table 7. Final consensus ranking based on the Copeland method

\begin{tabular}{cc}
\hline Material & Rank based on Copeland \\
\hline M1 & 10 \\
\hline M2 & 9 \\
\hline M3 & 8 \\
\hline M4 & 6 \\
\hline M5 & 5 \\
\hline M6 & 2 \\
\hline M7 & 4 \\
\hline M8 & 3 \\
\hline M9 & 1 \\
\hline M10 & 7 \\
\hline
\end{tabular}

The Copeland method's outcome reveals that the best material is M9, followed by M6, M8, M7, M5, M4, M10, M3, M2, and M1. To compare the final consensus ranking based on the Copeland method, the study conducted by Jee et al. (2000) is considered. They examined different cases, in some where M9 was chosen as the best material, and in others M6 was recommended as the optimum material along with M1 and M3. In their study, subjective weights and objective weights provided by the entropy method were considered, and TOPSIS was adopted to rank the alternative materials. The ranking result in the present study is consistent with their cases, in which M9 was found to be the optimum material. M6 was ranked second in the present study meaning that this material can be substitution material to M9.

The results reveal that the best alternative varies depending on what weighting method and MADM method are preferred. Therefore, recommending the best material based on a single model may be misleading. Instead, applying multiple methods and considering all models' results can increase the accuracy of the alternatives' ranking. Still, there are some limitations to this study. The number of weighting and MADM methods might be higher to increase the accuracy of the result further. Also, the scope and number of evaluation attributes might be expanded to cover further aspects. Finally, all possible alternative materials might increase the possibility of the proposed approach applicability in practice. However, it is a fact that the proposed approach is proven to be a practical approach by implementing the illustrative example and comparing 
the results with the previous ones. The proposed approach has also brought a hybrid method, which provides a higher accurate ranking compared to other related studies, for the material selection problems.

\section{CONCLUSIONS}

The present study has presented a hybrid approach to solve the problem of material selection involving various conflicting attributes and alternative materials in practice. It was often emphasized that adopting a single model and making decisions depending on the model could be misleading, as they might yield different outcomes for the same decision problem. Accordingly, two objective weighting methods (CRITIC and SD) and three MADM methods (GRA, ORESTE, and TOPSIS) were adopted and integrated through the Copeland method in this study. The proposed approach was implemented to the material selection for a flywheel.

The results indicated that all models except the CRITIC-ORESTE model recommended M9 as the best material. Similarly, the integrated ranking through the Copeland method revealed that M9 was the optimal material. However, the final rank based on the Copeland method is different from some models. This outcome is consistent with the claim that relying on one model may be deceptive. In this regard, if one has to choose one model for the problem considered, CRITIC-ORESTE is recommended to be avoided as it suggested a different material (M6) as the best from the Copeland method. Instead, CRITIC-GRA, SD-GRA or SDORESTE may be preferred as they offer M9 as the best material followed by M6, similar to the Copeland method. In addition, the results provided by Kendall's correlation coefficients revealed that the outcome of most models was strongly correlated. CRITICTOPSIS and SD-TOPSIS provided the same rankings that might indicate that TOPSIS was the most robust method for the problem considered compared to the ORESTE and GRA methods. The ranking provided by TOPSIS was not altered by the weighting method.

Future studies may consider using further weighting and MADM methods and integrate their results. Experts' subjective evaluations can also be included through subjective weighting methods such as AHP and the best-worst method. Finally, the number of evaluation criteria and alternative materials can be expanded.

\section{CONFLICT OF INTEREST STATEMENT}

The author declares that there is no conflict of interest in this study.

\section{RESEARCH AND PUBLICATION ETHICS STATEMENT}

The author declares that the research and publication ethics are complied with in the study.

\section{REFERENCES}

Chan, J.W.K., Tong, T.K.L., 2007. Multi-criteria material selections and end-of-life product strategy: Grey relational analysis approach. Materials \& Design, 28(5):1539-1546.

Chatterjee, P., Athawale, V. M., Chakraborty, S., 2011. Materials selection using complex proportional assessment and evaluation of mixed data methods. Materials \& Design, 32(2):851-860.

Deng, H., Yeh, C.-H., Willis, R. J., 2000. Inter-company comparison using modified TOPSIS with objective weights. Computers \& Operations Research, 27(10):963-973.

Deng, J.-L., 1982. Control problems of grey systems. Systems \& control letters, 1(5):288-294.

Dev, S., Aherwar, A., Patnaik, A., 2020. Material Selection for Automotive Piston Component Using Entropy-VIKOR Method. Silicon, 12(1):155-169.

Dhanalakshmi, C.S., Madhu, P., Karthick, A., Mathew, M., Vignesh Kumar, R., 2020. A comprehensive MCDM-based approach using TOPSIS and EDAS as an auxiliary tool for pyrolysis material selection and its application. Biomass Conversion and Biorefinery.

Diakoulaki, D., Mavrotas, G., Papayannakis, L., 1995. Determining objective weights in multiple criteria problems: The critic method. Computers \& Operations Research, 22(7):763-770.

Dortaj, A., Maghsoudy, S., Doulati Ardejani, F., Eskandari, Z., 2020. A hybrid multi-criteria decision making method for site selection of subsurface dams in semi-arid region of Iran. Groundwater for Sustainable Development, 10:100284.

Emovon, I., Oghenenyerovwho, O.S., 2020. Application of MCDM method in material selection for optimal design: A review. Results in Materials, 7:100115.

Hwang, C.L., Yoon, K., 1981. Methods for multiple attribute decision making. In Multiple attribute decision making (pp. 58-191): Springer.

Jahan, A., Mustapha, F., Ismail, M.Y., Sapuan, S.M., Bahraminasab, M., 2011. A comprehensive 
VIKOR method for material selection. Materials \& Design, 32(3):1215-1221.

Jee, D.H., Kang, K.J., 2000. A method for optimal material selection aided with decision making theory. Materials \& Design, 21(3):199-206.

Jeya Girubha, R., Vinodh, S., 2012. Application of fuzzy VIKOR and environmental impact analysis for material selection of an automotive component. Materials \& Design, 37:478-486.

Kendall, M.G., 1948. Rank correlation methods. Oxford, England: Griffin.

Kumar, R., Jagadish, Ray, A., 2014. Selection of Material for Optimal Design Using Multi-criteria Decision Making. Procedia Materials Science, 6:590-596.

Liang, R.H., 1999. Application of grey relation analysis to hydroelectric generation scheduling. International Journal of Electrical Power \& Energy Systems, 21(5):357-364.

Madhu, P., Sowmya Dhanalakshmi, C., Mathew, M., 2020. Multi-criteria decision-making in the selection of a suitable biomass material for maximum bio-oil yield during pyrolysis. Fuel, 277:118109.

Maity, S.R., Chakraborty, S., 2013. Grinding Wheel Abrasive Material Selection Using Fuzzy TOPSIS Method. Materials and Manufacturing Processes, 28(4):408-417.

Maity, S.R., Chakraborty, S., 2015. Tool steel material selection using PROMETHEE II method. The International Journal of Advanced Manufacturing Technology, 78(9):1537-1547.

Niu, J., Huang, C., Li, C., Zou, B., Xu, L., Wang, J., Liu, Z., 2020. A comprehensive method for selecting cutting tool materials. The International Journal of Advanced Manufacturing Technology, 110(1):229-240.

Roubens, M., 1982. Preference relations on actions and criteria in multicriteria decision making. European Journal of Operational Research, 10(1):51-55.

Şahin, M., 2020a. A comprehensive analysis of weighting and multicriteria methods in the context of sustainable energy. International Journal of Environmental Science and Technology.

Şahin, M., 2020b. Hybrid Multicriteria Group DecisionMaking Method for Offshore Location Selection Under Fuzzy Environment. Arabian Journal for Science and Engineering, 45(8):6887-6909.

Shanian, A., Savadogo, O., 2006. A material selection model based on the concept of multiple attribute decision making. Materials \& Design, 27(4):329337.

Wei, G.-W., 2011. Grey relational analysis method for 2tuple linguistic multiple attribute group decision making with incomplete weight information. Expert Systems with Applications, 38(5):48244828.

Wu, H.-H., 2002. A Comparative Study of Using Grey Relational Analysis in Multiple Attribute Decision Making Problems. Quality Engineering, 15(2):209-217.

Yazdani, M., Zavadskas, E.K., Ignatius, J., Abad, M.D., 2016. Sensitivity analysis in MADM methods: application of material selection. Engineering Economics, 27(4):382-391. 